\title{
UNIVERSITYOF
}

FORWARD

THINKING

WESTMINSTER用

WestminsterResearch

http://www.westminster.ac.uk/westminsterresearch

\section{Blacklisting and its legacy in the UK construction industry: employment relations in the aftermath of exposure of the Consulting Association}

Druker, J.

This is the peer reviewed version of the following article: Druker, J. (2016) Blacklisting and its legacy in the UK construction industry: employment relations in the aftermath of exposure of the Consulting Association Industrial Relations Journal 0019-8692, which has been published in final form at https://dx.doi.org/10.1111/irj.12139. This article may be used for non-commercial purposes in accordance with Wiley Terms and Conditions for Self-Archiving.

The WestminsterResearch online digital archive at the University of Westminster aims to make the research output of the University available to a wider audience. Copyright and Moral Rights remain with the authors and/or copyright owners.

Whilst further distribution of specific materials from within this archive is forbidden, you may freely distribute the URL of WestminsterResearch: ((http://westminsterresearch.wmin.ac.uk/)).

In case of abuse or copyright appearing without permission e-mail repository@westminster.ac.uk 


\section{Blacklisting and its legacy in the UK construction industry: employment relations in the aftermath of exposure of the Consulting Association. \\ Janet Druker}

This paper explores responses to the exposure of blacklisting in the UK construction industry in the period following the closure of the Consulting Association (CA) in 2009. It asks whether employer collusion to blacklist in this way has been terminated and concludes that it is now largely of historical interest although other forms of antiunion activity continue. It highlights particularly the historic and continuing importance of 'double breasting' and reports on divergent employer paths in the aftermath of the exposure and subsequent closure of the activities of the Consulting Association.

Keywords: Blacklisting; employers' associations; double-breasting' Consulting Association; construction

Professor Janet Druker University of Westminster Business School, 35

Marylebone road, London NW1 5LS

drukerj@westminster.ac.uk 


\section{Blacklisting and its legacy in the UK construction industry: employment relations in the aftermath of exposure of the Consulting Association}

\section{Introduction and overview}

This paper explores responses to the exposure of blacklisting in the UK construction industry in the period following the closure of the Consulting Association (CA) in 2009. Firstly, it asks whether the historical practice of blacklisting has been terminated? Is blacklisting a thing of the past? Secondly, it reports on divergent employer paths in the aftermath of the exposure and subsequent closure of the activities of the Consulting Association. It considers the possibility that other antitrade union tactics are deployed in place of blacklisting and asks if there is evidence of a shift in attitudes toward trade union organisation. Thirdly, it considers union positioning and implications for the future.

Blacklisting - the attempt by employers or employment agencies to avoid employing a known trade union activist by compiling or referring to an information database has a long history within the UK construction industry, where it is particularly difficult to bring about effective trade union organisation (McIvor, 1988). Through collusion between employers, workers have been denied employment or engagement and union organisation has been undermined. It has been a part of the approach to construction workforce management in the UK because of the challenge of sustaining direct supervision and effective line management in a workplace or work situations that vary daily and where employer control is difficult to sustain. 
Blacklisting is not exclusive to construction of course and is certainly not exclusive to the UK since dismissal of union members was a significant feature of mid-twentieth century anti-Communist activities in the USA (Filippelli and McColloch, 1995: 155). The activities of the UK construction employer alliance, the Consulting Association (CA) were terminated in 2009 amid a flurry of publicity that tarnished the reputation of the companies who had been associated with it. The CA staff had monitored individuals, especially those from the construction industry, whose names had been associated with trade union, environmental or socialist activities and provided information about them, through a subscription service supported by major construction contractors and employers. They were able to access information and use it as a basis for decisions about employment. The Office of the Information Commissioner closed down the CA in 2009 (Institute of Employment Rights, 2013).

The House of Commons Scottish Affairs Committee (SAC) exposed the activities of the Consulting Association with hearings taking place between 2012 and 2015 (House of Commons (HoC) SAC, 2013; HoC SAC 2014, HoC SAC 2015). The evidence before the Committee and publicity concerning blacklisting at the time of the hearings aroused outrage amongst those who had been denied work and widespread concerns amongst the communities of trade unionists, academics and HR and employment professionals who saw the activities of the CA as both undermining collective employment rights and also prejudicing individual employment opportunities. At the time of writing a legal hearing is pending, initiated by blacklisted workers against McAlpine who enjoined other construction companies associated with the $\mathrm{CA}$, who now defend the case with them (Building Magazine, 
09.08.2013: 13). Some blacklisting victims have already been awarded substantial compensation and further cases are under consideration.

This paper argues that blacklisting in the form in which it appeared via the CA is a historic phenomenon unlikely to return. Employers have grouped together in their legal defence against compensation for blacklisted workers and have, together, admitted liability and offered an apology (Syal, 2015). At the time of writing a Court case is pending. Yet the ending of this form of blacklisting may not bring an end to anti-union initiatives. There is evidence that paths diverge in enterprise practice with research pointing to some positive initiatives where client requirements and the influence of parent companies are brought to bear. However, contextual factors impact on management behaviours in different ways. A legacy of low trust remains, together with a belief, not confined to trade union representatives, that anti-union behaviour will be continued in some form. The short-term and peripatetic nature of construction work, the effects of sub-contracting, the use of self-employed labour through agencies and umbrella companies as well as the number of non-English speakers on some sites continue to make it difficult for trade unions to organise effectively at site level.

The paper is structured as follows. Firstly we discuss the literature that deals with employer resistance to trade unions and offer a brief overview of the history of blacklisting in construction. We explain the research design and methodology underlying this paper and then report on findings. Finally, we comment on the questions posed. 


\section{Employer resistance to trade unions}

Whilst there are studies that address the challenges of trade union organization at an industry level (e.g. Heery et al, 2004) interest in employer resistance to trade unions in the UK has largely focused on the question of trade union recognition within the enterprise, particularly following the creation of the statutory mechanism for trade union recognition (e.g. Dundon, 2002; Gall, 2004). An employer alliance such as the

$\mathrm{CA}$, co-existing with the structures of national collective agreements and providing a collaborative form of employer resistance to trade union organization, is different from resistance to recognition evidenced in enterprise based examples and deserves separate attention.

Kelly (1998) argues that conflict is inherent in the employment relationship and that employers will inevitably seek to resist unionization. He points to the tactics that are deployed to contain union power including legislation to curb strike action and derecognition of unions (P. 102). It is a view echoed by Smith and Chamberlain in their account of the effects of blacklisting as they report stories of victimisation and intimidation in the construction industry going back over many years (although they use the term 'blacklisting' to encompass a range of other anti-union initiatives) (Smith and Chamberlain, 2015). In a study of employer resistance to trade union organisation in the textile industry of the southern USA, Roy (1980) highlights the diversity of employer anti-union responses, ranging from intimidation (fear stuff), the offer of benefits or personal advantage (sweet stuff) and anti-union propaganda association trade unions with the forces of evil (evil stuff). Even where the union wins representation rights, employer resistance may continue and union organising efforts 
prove futile (fatal stuff). Gall (2004) extends Roy's typology whilst focussing particularly on union recognition campaigns but the classifications offered do not encompass the silent operation of an external anti-union body such as the CA. Logan, (2006) reporting on anti-union initiatives in the regulatory climate of the USA points to the importance of external actors, including consultants, law firms, industry psychologists and strike management firms, but does not refer to employer collusion. Significantly for our argument, Logan points out that organisations that support antiunion behaviour by employers, themselves experience a fall in business as union strength declines.

Heery and Simms (2010), reviewing the effectiveness of union organisation campaigns, point to the importance of employer policy as an important influence on the potential for unionisation. Employers may co-operate and form alliances to deal with trades unions, but they may also adopt divergent paths in their responses to union organising campaigns. Whilst some resist unionisation, others deploy alternative forms of worker participation. The response they make may be shaped by public policy and in some instances they may not seek to block unionisation. In some cases, they say, there will be no one dominant response and a contingency perspective may apply. A contingency perspective suggests that variations in product markets, ownership and governance arrangements and business strategy and structure will all play a part in shaping employer responses (Purcell and Ahlstrand, 1994). Dundon (2002) points to the complexity of workplace processes and the importance of structural, ideological and cultural factors in shaping employer anti-union activities. He dismisses the quest for 'management style' (Purcell, 1987) on the basis that such typologies have a tendency to represent the 'ideal' rather than the 'real' (Dundon, 
2002: 235). However, Purcell argued that "if management style exists at all...we have to allow for an element of choice which might be more or less constrained. Thus the study of management style is not primarily an analysis of outcomes but of originating philosophies and policies which influence action." (Purcell, 1987: 534). Dundon's analysis of the complexities of workplace processes is relevant to this account but so too is the notion of management style in enterprises where there is a strong shaping influence from a parent company or founder.

A dual approach - known as double-breasting - is sometimes used by multinationals where collective bargaining is in operation in one location whilst elsewhere trade unions are resisted (Beaumont and Harris, 1992; Cullinane et al., 2012 and 2013 and Dundon et al (2015)). Northrup (1995) points to the ways in which such practices were deployed by US construction employers, using both approaches simultaneously for different sites (open and closed shop), with the intention of reducing the advantages and cost of the union mark-up on the unionised site. Cullinane et al (2012) argue that employer moves to adopt parallel and apparently contradictory perspectives on employment relations are not necessarily the product of carefully formulated, rational choice. Rather such perspectives may be random and ad hoc. The literature on double breasting has relevance to the discussion of blacklisting that follows because of the complex - and sometimes contradictory - perspectives that are in evidence within the UK construction industry.

We turn now to the history of blacklisting in construction and discuss the purpose that it has served. 


\section{Blacklisting: some history}

Blacklisting - taken here to mean the attempt by employers or employment agencies to avoid employing a known trade union activist by compiling or referring to an information database - has a long history within the UK construction industry (McIvor, 1988) where it is (and has long been) particularly difficult to bring about effective trade union organisation. Through a process of surveillance and record keeping workers were denied employment or engagement. It has historically been a part of the collective approach by employers to construction workforce management in the UK because of workforce mobility and the challenge of sustaining direct supervision and effective line management in a workplace or work situations that vary daily.

For the purposes of this narrative, the story begins with the Economic League, created in the aftermath of the $1^{\text {st }}$ World War. Blacklisting - countering subversion in industry as it claimed - was a part of its activities since the 1920s (Economic League, 1981). Industrial conflict in the 1960s and 70s fuelled employer willingness to step up blacklisting in the construction sector (Winder, evidence, Scottish Affairs Committee, 2013: Ev188). The 1972 national building strike lasting for 13 weeks over the summer of 1972 took place at a time when the wider trade union movement was engaged in a battle against the 1971 Industrial Relations Act and the Government had determined to crack down on trade union resistance (Wood, 1979, chapter 1). The strike itself was ultimately resolved through the national negotiating machinery then in place but employers subsequently compiled a 'dossier' of picketing activity that was presented to government ministers (Wood, 1979:31). Action for criminal conspiracy followed and six trade union activists were imprisoned as a consequence. 
Significantly, public files relating to this aspect of the strike have yet to be released so a full understanding of events - particularly of the relations between employers, the Police and Government of the day - is more limited than it should be (Boffey, 2015).

After 1972 this legacy weighed on employer attitudes to the management of industrial relations in the construction sector in three different ways. Firstly, it added weight to their reasons for deploying sub-contractors and self-employed labour-facilitated by the 1971 Finance Act which introduced the construction industry tax deduction scheme (Seely, 2015: 12). Secondly, it fostered continued support by employers for national collective bargaining since the 1972 strike and subsequent court cases served to separate national union leaders from their own activists, facilitating dispute resolution at national level at the expense of rank and file action (Wood, 1979: 33). Employers' associations in building and civil engineering, as well as in electrical contracting, plumbing and engineering construction, continued national level negotiations with trade unions for the whole of this period. Thirdly, it encouraged some major employers to continue their support for blacklisting as a final line of defence against trade union militancy through the Economic League until its closure in 1993 and then subsequently through the Consulting Association.

The Economic League was a phenomenon reflecting the political polarisation of the years between 1919 and 1993. In a world divided between communism and capitalism its espoused purpose was to resist subversion in industry and, with the ending of that chasm in global politics, with the collapse of the Soviet Union and the satellite economies, it might have seemed that the battle had been won. Communism was 
defeated and with that defeat came the ending of communist influence in trades unions. But this was not the end of blacklisting.

Records of the Services Group of the League, concerned particularly with construction, were transferred to the CA, established at about the same time and supported by Robert McAlpine Ltd. Some 18 major construction companies were affiliated at the outset (HoC SAC, 2013: Ev138). ${ }^{1}$. According to accounts given to the Scottish Affairs Committee, the CA provided three key services to subscribing companies. Firstly it held a 'bank of information' or blacklist that could be accessed via subscribing companies. Where a company submitted individual names of potential workers, staff at the CA would undertake a search for which an additional charge was made and provide a return to the subscribing company indicating whether any of the names were on the CA list. Companies also had the right to update information held and in this way could participate actively in sharing their views for blacklisting purposes. Secondly, the CA held networking events. Thirdly, searches of radical literature were used to update the files. Where an organisation wanted information it was customary for a list to be faxed across to the CA, for the checks to be undertaken and the CA to phone back to a named contact - an HR or industrial relations manager - with a response (Notes (typescript) from Ian Kerr, dated 23/12). An odd feature of the arrangement was that by this stage many of the major contractors who were associated with this practice employed very few workers - most being engaged through the supply chain. Given a new burst of life by disputes in the electrical contracting sector toward the end of the $20^{\text {th }}$ century, particularly on the Jubilee Line

\footnotetext{
${ }^{1}$ John Laing, Tarmac, Amey, Amec, Ballast Wiltshier, Taylor Woodrow, Walter Llewellyn, John Mowlem, Balfour Beatty Construction, Trafalgar House, Balfour Beatty Civils, Higgs and Hill, Kier, Norwest Holst, Nuttalls, Morrison Construction, Willmott Dixon and Sir Robert McAlpine
} 
Extension, the CA continued its work as a subscription organisation providing blacklisting services until 2009, by which time media reports had exposed activities that were then challenged by the Information Commissioner who closed the organisation down. The Blacklists Regulations, proposed at an earlier date but not enacted, were brought into effect by the Labour government in 2010 (Blacklists Regulations, 2010).

Over the past six years blacklisting activity has been scrutinised particularly through the enquiries of the Scottish Affairs Committee (HoC SAC 2013; 2014 and 2015). Public exposure of the CA raised questions about the effectiveness of the mandate of the Information Commissioner and about data protection in practice and it accompanied changes both in the law and in professional standards. In 2010 the Employment Relations Act 1999 (Blacklists) Regulations 2010 (SI 2010/493) were finally brought into effect (they were originally proposed in 1999) making it unlawful to compile or to use a blacklist, with compensation for those who suffer as a result of being blacklisted.

The 2010 Regulations were given effect as a consequence of the exposure of the activities of the CA in the previous year. It appeared that some professionally qualified human resource practitioners were implicated and in December 2013, following the appearance of the Chartered Institute of Personnel and Development (CIPD) Chief Executive Officer (CEO), Peter Cheese, before the Select Committee the CIPD published a guide to pre-employment checks, which dealt specifically with the issues of blacklisting and with 'lists of high risk candidates' (CIPD, 2013), setting more specific professional standards for CIPD members. The SAC, unconvinced by 
the evidence they had received, argued in response that a statutory code is needed (HoC, SAC, 2015 para 50).

The right to freedom of speech, the right to join a trade union and to take part in trade union activity are fundamental human rights, acknowledged in the Universal Declaration of Human Rights. It is disconcerting then to hear that activists in the construction sector believe that 'blacklisting is continuing...' and there remain suspicions that contractors keep their own blacklists (Building Magazine 31.05.2013: 23).

Trade union leaders are on record as saying that they believe the practice continues: e.g.

"probably not in the way that it was happening in the past when there were files made and all that, but by word of mouth"

Steve Murphy, then General Secretary, UCATT, Evidence at the HoC SAC, 22 January 2014.

High court action in relation to blacklisting was begun in March 2012 with a claim on behalf of the BSG for 79 individuals against Sir Robert McAlpine. Ten of the other major contractors were subsequently added as co-defendants, reducing to eight by 2015. Eight construction companies admitted their association with the CA and apologised collectively (through a press release) on October $10^{\text {th }} 2013$. The construction unions, the GMB, UCATT and UNITE initiated High Court claims in 
2013 reflecting the groundswell of opinion - both from the BSG and from senior union officers - that the major contractors should provide financial recompense for their role in blacklisting (Guney, Clark and Ryan, 2014). Some of the legal cases on behalf of over 600 individuals have now been settled whilst others are outstanding.

In the meantime a further collaborative initiative by employers, the Construction Workers Compensation Scheme (CWCS), was launched with the intention of resolving claims outside of the courts. The Scheme was discussed with construction trades unions without agreement being reached, but was launched and publicised by the contractors' group to MPs with a message that implied union involvement (HoC SAC, 2015). Perhaps predictably, the unions had been unwilling to agree the terms but with this public relations 'own goal' the contractors left the moral high ground to the BSG.

The CWCS offers a fast track route to a payment up to a maximum of $£ 20,000$. A full review, involving a calculation of loss of earnings could lead to an award of up to $£ 100,000$. It is a condition of joining that applicants will not bring or continue to pursue any claims through the court. Free legal advice is available to potential applicants before entering into this process, enabling people to think about how to approach the claim - whether to follow the fast track route or to opt for a full review toward a bigger claim (HoC SAC, 2015). Given the age profile of many of the claimants (many of whom were blacklisted decades ago) it may seem surprising that so few have opted for the CWCS. As of March 2015 only 149 people had been compensated through that route (Guardian 27 March 2015: 2), compared with some 650 legal claims pending (interview data; professional). The scheme is distrusted by 
union activists and the claimants' representatives have sustained a high degree of coordination in resisting the potential attractions of what could seem to be the easy access route to redress.

The SAC evidence highlighted the differences emerging between the main contractors involved. Some of them denied involvement whilst eight companies acknowledged their participation in the CA (HoC SAC, 2015). Sir Robert McAlpine, a family firm rooted in right wing Conservatism, claimed that CA activities were a normal part of HR practice. The company had been a founding influence in the CA and a key player within the Economic League before it. Cullum McAlpine, representing the company denied that their participation constituted blacklisting. Rather, he suggested, it was an attempt to avoid engagement of those who might wreak damage on the industry or on particular projects “sabotaging construction activities and unlawful activities" (HoC SAC, 2013, HC156-1: Ev 171).

Other employer representatives before the SAC took a more conciliatory perspective. For example, Callum Tuckett, Group Finance and Commercial Director for Laing O'Rourke publically acknowledged that his firm was involved, recognising that the company's behaviour had been unacceptable (HoC SAC evidence, 16 $6^{\text {th }}$ July 2014).

Despite this, senior union figures maintained that there is both a history and an ongoing breach of fundamental human rights within their industry. Their views prompt a reiteration of the key research questions - does blacklisting continue? How united are employers in their response to the exposure of the CA's practices? And what position are unions taking? These questions are considered in the research findings. First 
though, it is essential to comment briefly on the research design and on the ethical position taken in the course of this work and these issues are considered in the next section.

\section{Research Design}

This research project drew initially on evidence included in the House of Commons Scottish Affairs Committee reports, and additionally on media reports, blogs and other on-line resources concerned with blacklisting. Given the sensitive nature of the questions, subsequent research was qualitative in nature and the project developed on the basis of semi-structured interviews with a range of individuals within the industry. To date 23 interviews have been concluded including one client; five senior managers employed by major contractors; one sub-contractor; two employer representatives; five operatives or former operatives; two union full-time officers; two site level union representatives and five others from professional or advisory organisations. Two sites were visited, both in London. All of the contractors involved in current litigation were invited to participate but only two chose to do so. Inevitably this constrains understanding of the different paths employers are pursuing, although this disadvantage is to some extent offset by the participation of clients, professionals and trade unionists who have experience across the industry. Five of the interviewees had themselves featured in the CA lists because of trade union activity although not all of those who were listed suffered loss of employment as a consequence.

The topic is a sensitive one both for contractors and for trade union activists since litigation is in progress and interviewees were advised that their participation would be treated as confidential and that neither they nor their organisation would be 
identified in any subsequent publication. Interviews were recorded and interviewees were invited to check the notes of interviews to ensure accuracy. Research was undertaken in accordance with the Ethics Code for Research of the University of Westminster.

\section{The Current State of Play}

\section{Does blacklisting continue?}

Despite the assertions made at the Scottish Affairs Committee and elsewhere (Building magazine - cited above) there is at present no tangible proof that there still exists an employers' association to blacklist union activists, although there have been allegations about the activities of the Employment Agency, known as Atlanco Rimco (SAC 2015). Steve Murphy, General Secretary of UCATT stated before the Committee that blacklisting was continuing suggesting that it could operate 'by word of mouth'. Yet blacklisting of the type operated by the CA relied on employer collaboration, on documentation and on reference to a database to process names. It may be that this did not seem relevant to Murphy at the moment of giving evidence but it is an important consideration. Union leaders speaking before a Labour-leaning Committee wanted to ensure that they were not wrong-footed by rank and file activists in the Blacklist Support Group (BSG) because some union officers were alleged to be complicit in blacklisting. It may also be the case that senior union officers were catching up with the position adopted by their own rank and file because the unions had been slower than the BSG in taking up the legal defence of blacklisted 
workers. Yet an important distinction must be made between the paid for blacklisting practices deployed by the CA, external to the enterprise and other anti-union actions.

The Chairman of the Scottish Affairs Committee, (2014:41) said: -

"The fact that someone may informally ring somebody else is not a structured blacklist'.

In contrast with the public positioning of union leaders, union interviewees for this research expressed doubts about the issue in comments that suggested an absence of trust. They pointed to a lack of evidence that blacklisting continues arguing that employers would be constrained by new regulations yet suspicions remain, chiefly that individual contractors retain their own lists.

"I've not had anyone sort of say to me, even in my branch, that I'm having problems getting on a job, or I've been on a job for a day and I've been sacked. So I can't answer that question. I would like to think that it has ended. I'd like to think that the outcome of this when it's all done and dusted is that if people are going to go down that road then the law won't take very kindly and that people will be fined very heavily...” Union convener - formerly blacklisted

Complaints about blacklisting, if it is occurring, would be made to the ICO's Office, yet that Office has no evidence to substantiate the claims of continuing blacklisting and their investigations into this issue are now closed (Information Commissioner's office, 2015/2016). 
In the view of one professional representative interviewed, the CA's activities were "sloppy and pointless". The quality of information was poor and no one was likely to want to do that again.

Anti-union employers in all sectors have a variety of other weapons at their disposal when they are dealing with union activists and blacklisting is only one of them. As one union officer put it in an interview, for some people who are well known activists, employers don't need a blacklist - individuals are known by their reputation. However such cases would be low in number. Disciplinary procedures, transfer of staff from one site or work location to another, dismissal and redundancy may result from antiunion sentiment but may not characterise the entire industry although such actions are a part of the wider industrial relations landscape. A schema of anti-unionism (of the type offered by Roy, 1980 and elaborated by Gall, 2004) requires flexible interpretation and an understanding that whilst one approach may have been favoured over others, employer tactics will vary and may change over time.

Historically blacklisting has served as one of a range of negative employer devices to maximise employer control at site level and it is impossible to rule out the risk, as one interviewee suggested, that at enterprise level, lists are maintained to prevent known activists being recruited.

'Does blacklisting continue at company level?' (Interviewer) "I would say so, yeh. I think...it wouldn't be as widespread as it was. There might be a company - let's say for instance McAlpines - that would probably, they'll have something the amount of 
jobs they have, it's sort of... If someone wasn't liked because of his health and safety views, I think they might have something in house where they'll say we'll make sure we don't employ you again”.

Convener, formerly blacklisted

Another interviewee (employer representative) said that it is right to be concerned about the use that employers might make of social media.

It is not the purpose of this paper to debate the position of individuals who say that they have been blacklisted, but where particular cases were analysed by a former blacklisted worker their substance was disputed (Wainwright blog, 2013). Our understanding should be tempered with the awareness that campaigners might use the term 'blacklisting' to encompass a much wider span of employer activities reflecting resistance to union activity on site.

The majority of contractors currently defending their involvement with the CA - and of course there are others who were not involved - have Codes of Ethics and commitments on health and safety management that suggest that union involvement should be welcome. Yet it is difficult to foster a climate of trust and mutual respect against the backdrop of a negative legacy and some of the comments made by interviewees reflect the suspicions that remain. In an industry in which employment is insecure and short-term, where self-employment and agency labour are widespread, threats and fears of unemployment constitute a powerful disincentive for individuals to join a union or stand for union office. Only significant and positive employer responses could enable a more positive employment relations climate. 


\section{Employer Responses}

The eight contractors who acknowledged their involvement with the CA are currently allied in their legal representation in defending the case against them and they are at the time of writing, seeking to minimise damages (Interview with legal specialist). Others have denied involvement even though in some cases their organisations had demonstrable previous connections to the CA. Despite collaboration on the legal front, there are differences between construction leaders in their attitude toward trade unions and the management of employment relations, reflecting amongst other factors, the nature of their organisations, the influence of founders or of parent companies and the values of the clients that they serve.

The general context of operations is as follows. Whilst forms of contract vary in the construction industry, there is in general a well-established process, whereby major contractors compete for contracts, sometimes alone, sometimes as part of a joint venture and on occasions with the co-operation of major sub-contractors. Management of the supply chain is critical to effective performance and tier one subcontractors will be carefully selected and able to perform in the way prescribed by the main contractor (Mead and Gruneberg, 2013) .

"We like to think we employ competent, reliable contractors, which we do in the main through an extensive audit process before we get them onto our framework if you like, so there's a degree of confidence that they're going to employ people properly, perform properly once they're on the project... But .... it's fair to say, we rely on our 
trade contractors to comply with their contract obligations and, stating the obvious, to comply with the law..."

\section{Project Director Company A}

Contracts are parcelled out to sub-contractors, who in turn often sub-sub-contract, with employment responsibilities often transferred to agencies who use pay-roll or 'umbrella' companies to pay self-employed workers (interview data - project director and self-employed operative). Some of the bigger sub-contractors, for example in building services, retain significant core numbers of employees but will also use selfemployed workers to expand their workforce when required. This approach to management may have its origins in financial expediency but the fragmentation that results diminishes the likelihood of effective trade union organisation. It is compounded by the short time span that many workers are on site and, in London at least, by the variety of languages spoken. Romanian, Punjabi and English were the main languages for induction on the two (London) sites visited. Some non-English speakers relied on a group leader who could speak English in order to communicate and as the convener steward commented, there is no way of knowing whether that individual also functions as a ganger. It is important to note that in general the major contractors would have no direct control over who the sub-contractors bring on site other than to ensure that they have the right to work in the UK and that they have the skill level and health and safety accreditation that is required by the Construction Skills Certification Scheme (CSCS) (interview - project director).

Within this overall context, two key factors appear to be at work in shaping the position adopted by major contractors; external or client-focussed and internal or 
enterprise focussed. Despite the association between employers on the legal front, evidence suggests that there are significant differences at enterprise level.

The influence of the client and the nature of the individual contract on which the contractor is engaged is a key determinant of contractor attitudes and behaviour in relation to trade unions - attitudes and behaviour which may be passed on through the sub-contracting process to their tier 2 or tier 3 sub-contractors. This influence may be positive. One (client) interviewee outlined his approach and expectations for a major project, saying that he often referred back in his thinking to positive developments on other major projects - notably Heathrow T5 and the London 2012 Olympic site. He was aware that the contractors working (or expected to work) on his project had been engaged in blacklisting in the past but his project would aim for structural arrangements that provide direct employment and the opportunity for a union presence. In this context contractors - some of them with a history of blacklisting will have an interest in compliance and in co-operation with unions and auditing arrangements will be set in place to ensure that this is what they do. Public sector contracts, those with more experienced clients and those with a significant public profile - hospitals, local authority contracts and universities - may follow a similar pattern. Other clients by contrast may have little interest in improving work and employment practice. For many - including some in the public sector - the concern is primarily with controlling cost and ensuring timely project completion, factors that may operate to the detriment of union organisation. In some cases - and one interviewee suggested that this was the case with the Ministry of Defence when it is a client - there may be an interest in actively preventing unionisation. Since contractors may, at any given point, hold contracts with a variety of different types of client, they 
are likely to adopt a pragmatic, double-breasted approach to trade unions unless there are other factors at work which influence the approach to be taken.

Internal or enterprise focussed factors also influence attitudes to trade unions as employers grappled with their responses to blacklisting.

In one enterprise (referred to here as Company A), a UK subsidiary of a European multi-national, this meant that the company was influenced by a parent organisation which had a strongly stated ethical position, adopting a positive approach toward trade unions at European level and according to one union participant, working constructively with its European Works Council (Interview - Convener steward). Confusingly, this had not prevented that company from allying itself with the CA, and from falling into the practice of regularly consulting the database and using it to influence employment decisions in some parts of the operation. Although no evidence was found to support the view, union members employed by the company suggested that this behaviour had been influenced by the requirements of Ministry of Defence contracts, pointing out that whilst actively engaged with the CA, the company also and over the same period of time, liaised with trade union officers and employed full-time convener stewards on others. Random and ad hoc though this juxtaposition may seem, there was a clear and unambiguous statement of position, influenced by the parent company and by a reassertion of ethical principles after the CA activities were exposed. Even prior to that point, the company had been seeking to develop a more fully-fledged HR strategy and the HR Director reported that news of the CA's existence and function had been a catalyst for further change (interview). Influenced by the values of the parent, company, Company A's response involved a 
systematic and through-going investment in transformation after 2009. It included a change of personnel responsible for HR practices in the part of the company most affected; the appointment of a new, senior level, IR manager; setting up an investigation and a review of policies and processes; a tightening up on referencing and a reminder to leaders of business units about the organisation's referencing policy; a code of practice for sub-contractors; and reinforcement of a code of ethics with regular discussion of ethical issues across all sites and involving all site managers. Union officers, from different unions and unconnected with the company, commented that "Company A did change".

A site convener commented in this case: -

"I think that (Company A) have moved on from the blacklist - I think that most of the firms have moved on from the blacklisting now. Some firms might like to go on doing it but they've been caught out so they've stopped doing it for a reason - but there's other firms out there who've realised that its morally wrong. I think that (Company A) actually realised that...that it's morally wrong to do that"

Mergers and acquisitions may have drawn some enterprises into the CA network. Laing O'Rourke's Finance Director acknowledged that the firm had been involved, but said that this was a consequence of O'Rourke's acquisition of Laing and Crown House Engineering in 2004. Interestingly, Laing O'Rourke, like some of the other companies with Irish origins, is reputed to have a strong culture and to be distinctive because it is more likely to employ workers direct (Interview - professional). Anecdotally it is also more likely to prefer a non-union environment. 
Not all of the contractors demonstrate the influence of enterprise values in the same measure. Like others, Company B had a history of engagement both with trade unions and with the CA. They had sustained involvement with national collective bargaining and observed the protocols associated with the national agreement to the extent that trade union officers were allowed access to the workforce. A senior interviewee suggested that, since use of the CA had been limited, there had been no need for a radical review of policies after its activities were exposed.

In concluding this section then, we note that some of the bigger clients play an important part in shaping contractor/supplier relations and as a second order issue (for them), the climate for employment relations. Major projects are sometimes shaped in turn by public policy - either positively or negatively (client interview). Whilst this was the case in a positive fashion at the London Olympic site (Druker and White, 2013) and at Heathrow T5 (Deakin and Koukiadaki, 2009), interviewees suggested that the Ministry of Defence, as a client, was behind some of the impetus for blacklisting in the past, but we have no other evidence to substantiate this view. Without conscious intervention from clients, the competitive environment drives a more random and ad hoc series of approaches that limits or works against unionisation encouraging the practice of double breasting. Company values and practices vary and, whilst employers had been associated together in the past through the CA and subsequently through legal defence of their behaviour, there is evidence of different - and in some cases more positive - routes being selected subsequently.

\section{Union positioning and the future of employment relations}


Trade unions have a limited presence in the construction industry although they are more effectively organised in engineering construction and electrical contracting than in building and civil engineering. Trade union membership and density in construction has declined slightly since 2008 (the year prior to the CA closure) from $17 \%$ to $13.8 \%$ (all employees) and from $16.7 \%$ to $15 \%$ for men (Department for Business Innovation and Skills (DBIS), 2015). Of course the blacklisting 'legacy' years comprise the period in which the construction industry absorbed the impact of the global economic crisis and employment opportunities and work conditions were severely affected by economic factors. The decline cannot then be interpreted as resulting from a change of direction or a more hostile climate in terms of employer attitude toward trade unions.

However construction union UCATT is certainly under pressure and, at the time of writing is confronting significant financial losses with a deficit of almost $£ 3.5$ million in 2014 (UCATT, 2014) and faces the prospect of being absorbed into another union most likely UNITE. This would leave two construction unions - UNITE and the GMB, with UNITE - which comprises the former EETPU (via Amicus) having the majority of blacklist cases to address. The survival of national collective agreements continues to provide a cloak of credibility for the unions but the reality for union officers is that site organisation is a continuing challenge, perhaps more easily confronted by the electricians, who featured disproportionately in CA files than by bricklayers or carpenters.

Blacklisting has become a totemic issue for construction unions. Their success in winning compensation for blacklisted workers could shore up their reputation for 
being able to do something for workers in the industry, perhaps countering the view (expressed by two non-union workers interviewed) that unions lack the power to defend worker interests. One interviewee suggested that trade union officers talk up the significance of blacklisting as a distraction from other challenges. Another suggested that, whilst they had pursued Employment Tribunal cases for individuals, they had done nothing to prompt a collective response.

Firstly, unions face the challenge of recruiting self-employed workers. Union membership was described as "a waste of time" by one interviewee (self-employed slip form operator), although another, commenting on the abuses of payroll companies said that his union membership gave him more control, power and backing if he had a problem.

Secondly, trade union officers are aware that their own reputations, or those of colleagues, have been called into question because of allegations that union officers were involved in identifying workers to be blacklisted, a view contested by some former union officers. One union activist reported that there were around 50 files that showed evidence of EETPU comment on individual job applicants. Whilst blacklist files indicate union sources of information about individual workers, they do not show that union officers or former union officers knowingly and deliberately provided information and this is certainly denied by some of those interviewed who point out that the data gathered about individuals in the CA files was often low-grade information that was already in the public domain and of no practical use to a potential employer. Allegations against union officers may be a legacy of inter-union rivalries and particularly of the mutual animosity between former officials of the 
Electrical Electronic Telecommunications and Plumbing Union (EETPU) from former activists of the Electrical Plumbing Industrial Union ((EPIU) - the union formed at the time when the EETPU was outside of the ranks of the Trades Union Congress (TUC)). The implications of this continuing controversy are that concessions by the main construction unions on the issue of compensation or any visible lessening of support for blacklisted workers could be interpreted or presented by former EPIU activists as suggesting that union leaders are at best not wholly committed to pursuing the issue to its fullest extent and at worst culpable of complicity with the employers.

Finally, in an industry where trade union organisation is an on-going challenge, union leaders are able to claim the moral high ground by supporting blacklisted workers. Whilst the CA may be of historic rather than current interest, union leaders are unlikely to forego the publicity associated with what they expect to be a winning legal case.

\section{Discussion and conclusion}

An employer association to contain the power of trade unions, the Consulting Association survived for many years as an alliance that operated covertly and with individuals unaware that they had been targeted. Like the external organisations identified by Logan (2006) as resisting unionization in the US, it was based outside of the workplace. Unlike those organisations, however, it was the result of employer collaboration, an initiative whose existence paralleled the lifespan of the legitimate employers' organisations, most recently, until it was disbanded in 2009, the 
Construction Confederation, which engaged in national collective bargaining with construction trades unions. These parallel forms of employer association constituted, in effect, a form of national 'double breasting' with enterprises associated who claimed to uphold national collective agreements resisting unionization at site level.

Employer values and practices appear then to be schizophrenic. Whilst the long survival of blacklisting suggests a concerted and employer coordinated form of antiunion operation, the perpetuation of national collective agreements acknowledged national-level union influence and enabled procedural consistency where employers needed it. Roy (1980) and Gall (2004) offer typologies of employer resistance in the face of union campaigns for representation rights but the survival of the CA following the collapse of Communism must be understood in a different way, in part a legacy of past practice, in part a reflection of deep and unreconstructed anti-unionism on the part of some leaders or industrial relations practitioners within major contractor organisations.

Employer values with regard to trade union organization are inherently pragmatic. They are not automatically or necessarily anti-union, although the espoused ideology of some senior characters within the industry suggests that this is the case. Rather, in line with comments from Heery and Simms (2010) they will accept and work with trade unions where this seems to be a requirement because of the nature of the contract or the environment in which they are located. Their responses to initiatives from trade union organisers are contingent upon business circumstances but also of course on the pressures to which they may be subject from union activists and campaigners. 
The CA seems to have been ill equipped to operate in today's employment environment, with little evidence of the systems that might be expected to be in place if it were seriously geared for its purpose. This is not to make light of the impact of its activities. The individuals who were pinpointed remained without work, sometimes for many years and suffered the devastating loss of their livelihood without knowing why this had happened. Yet the process was idiosyncratic and other activists, who were shop stewards, with long-standing commitment to their union activity, were apparently unaffected. The impression that is created is of an organization that was inconsistent in its approach and (fortunately) ill suited to its task of managing and communicating information. Had the CA been more efficient it could have been far more damaging.

Its survival through until the first decade of the $21^{\text {st }}$ century seems to be an anachronism. Blacklisting might have been expected to be of historic rather than current interest since the conflict that had marked construction sites in the 1960s and early 70s was no longer in evidence. Trade union organization in the private sector of the construction industry is now limited and outside of engineering construction and electrical contracting shop steward organization is uncommon. Direct employment has diminished and sub-contracting is the norm with workers often on site for very short periods of time, engaged through agencies, compounding the challenge for unions of recruitment. Labour mobility within the European Union means that the construction workforce is fragmented by language too with construction sites comprising workers from different parts of the EU and elsewhere. 
These developments suggest that an employer alliance of the type organised by the CA - bringing together different contractor organisations - is unlikely to be in existence today. It is difficult, of course to prove that there is no longer an interorganisational collaboration to blacklist and there are those who argue that web-based information and social media make it more, rather than less likely. However, there are two key reasons for believing that this form of anti-unionism is now primarily of historic interest. Firstly, firms that seek to manage their reputation and to win clients both in the private and in the public sector might be expected to operate lawfully and the law is tighter now than it was before 2010. Secondly, an employer alliance of the type that existed historically would be high risk, precisely because it is now specifically designated as unlawful and because of the possibility that a whistle blower could expose unlawful activities. This does not preclude on-line monitoring and enterprise level surveillance but even here, implementation of a blacklist would be a high- risk scenario for contractors who engage workers only through the subcontract process - and who would have to co-ordinate responses with and rely on the discretion of sub-contractors. Employer values reflect a variety of complex - and at times conflicting - pressures. These include the nature of the organisation and its history, the values and priorities of current leaders, the type of work that is undertaken and the degree of freedom and flexibility permitted to project directors and site level managers. To an extent, the approaches adopted historically were always inclined to be random but after the spotlight of public investigation and media coverage of the less savoury aspects of the industry's practices, there may be greater attention by decision takers to ensuring that their activities are at the least, lawful and within the framework of public accountability. 
Blacklisting of the CA variety will disappear, as Logan (2006) suggests, simply because it is no longer needed. Double breasting identified by Dundon, 2002; Cullinane et al, 2012; and Dundon, 2015 will continue, not on the Northrup model (1995) where non-union sites are used to counter the costs of those that are unionised. Rather, larger and more significant sites will continue to have a union presence where public policy, key clients or lead contractors play a particular part in setting standards, for example on direct employment, and access for union officers to recruit. Access to major contractors for the research for this paper was impeded because of concerns about litigation, but the evidence that has emerged points to the continuing influence of founders or parent companies in some cases in the responses to exposure of the CA. That influence has been blurred over time by the effect of mergers, especially when firms have come together with very different management styles giving rise to apparently schizophrenic views from management on the benefits or disadvantages of trade unionism. There are many different reasons why a site may be unionised and the fragmented nature of worker engagement is an on-going obstacle for union recruitment. Yet where a strong founder or parent company influence is in evidence (as sometimes it is), this provides a default setting for the direction taken after the demise of the CA.

In asking whether blacklisting continues, we cannot rule out a company level database (for example through an employment agency) being used to identify rank and file activists who have been perceived to constitute a risk to the smooth running of a site or project. Of course this is not the same as an employer alliance of the type provided by the $\mathrm{CA}$ and an infringement of data protection legislation could be more easily disguised within the enterprise and there might be a lesser likelihood of disclosure or 
whistleblowing. Yet since the construction workforce is highly mobile, the benefits of sharing information - with other contractors or with sub-contractors - would be lost. Indeed there are doubts as to the benefits for the individual employer. Many of the (relatively small number of) activists - in the Blacklist Support Group, for example are known by name within the industry and contractors do not need a register or data base to identify them and to prevent them from gaining employment. In practice, induction arrangements make it a relatively simple task to check names against those arriving for (or having passed through) induction. However we have no evidence that this is happening - only that people fear that it could happen. Such widespread fears betoken a low level of trust for the contractors who hold the power within this situation and do not promise well for the future of employment relations or for employee engagement within the industry. Poor industrial relations has the potential to bedevil contracts and that is particularly the case where the industry is buoyant and projects are at a stage that exposes their managers to the effects of industrial action for example of the type encountered by electricians on the Jubilee Line Extension.

Evidence suggests that, in line with findings from Wright and Brown, (2013), that union conveners, appointed by trade unions but on the payroll of contractors, play an important part in laying the basis for trade union organisation in circumstances where this would otherwise be impossible. Where the role exists (and it is not common), it allows for a measure of workforce participation, addressing individual grievances and focussing particularly on working conditions and health and safety issues, although it is rare to find interventions that relate to pay. It does not rule out the possibility of double breasting but it does provide a first line of defence for trade unions in an industry where there are otherwise few support mechanisms. 
The future of employment relations within the construction industry will be played out with different faces if UCATT disappears into UNITE or the GMB. On $1^{\text {st }}$ September 2015 a new employers' organisation was launched. Build UK brings together 27 of the industry's largest main contractors with a wide range of specialist contractors in the supply chain, opening the potential for clearer and more positive standards to be set on a number of major issues although not, as yet, collective bargaining. There is no necessary reason why industry standards in the construction sector have to be imposed by clients or by public policy but for the moment it seems that the ad hoc and reactive nature of management is likely to continue.

\section{References}

Beaumont, P.B. and Harris, R.I.D. (1992) 'Double breasted' recognition agreements in Britain. International Journal of Human Resource Management 3 (2) September: 267-283).

Blacklists Regulations (2010) Employment Relations Act (1999) (Blacklists)

Regulations, 2010 Terms and conditions of employment. Statutory Instrument no 493. London, Stationery Office.

Boffey, D. (2015) 'Revealed: how Ted Heath used TV film to wage bitter battle with striking builders'. Observer 06.12.2015: 20.

Building Magazine 31.05.2013: 23.

Building Magazine 09.08.2013: 13 Sir Robert McAlpine names rivals in blacklist defence.

Chartered Institute of Personnel and Development (2013) Pre-employment checks: an employer's guide. London, CIPD. 
Cullinane, N., Donaghey, J., Dundon, T. and Dobbins, T. (2012) Different rooms, different voices: double breasting, multi-channel representation and the managerial agenda. International Journal of Human Resource Management 23 (2) January: 368384.

Cullinane, N., Dundon, T., Hickland, E., Dobbins, T and Donaghey, J. (2013) Beyond Union Avoidance? 'Exploring the Dynamics of Double-Breasting Voice Regimes in Ireland' In Gall, G. and Dundon, T. (Eds), Global Anti-Unionism: Nature, Dynamics, Trajectories and Outcomes. Basingstoke, Palgrave Macmillan.

Deakin, S. and Koukiadaki, A. (2009) Governance processes, labour management partnership and employee voice in the construction of Heathrow Terminal 5.

Industrial Law Journal 38 (4) December: 365-389.

Department for Business Innovation and Skills (2015) Trade union membership 2014. Statistical Bulletin. June 2015. London, DBIS, Crown Copyright.

Druker, J. and White, G. (2013) Employment relations on major construction projects: the London 2012 Olympic construction site. Industrial Relations Journal 44 (5-6) November: 566-583.

Dundon, T. (2002) Employer opposition and union avoidance in the UK. Industrial Relations Journal 33 (3): 234-245.

Dundon, T. (2015) Double breasting employee voice: an assessment of motives, arrangements and durability. Human Relations 68 (3): 489-513.

Economic League (1981) The agitators: political extremists in industry. London, Economic League.

Filippelli, R. and McColloch, M. (1995) Cold war in the working class: the rise and decline of United Electrical Workers. State University of New York Press, Albany, New York. 
Gall, G. (2004) British employer resistance to trade union recognition. Human

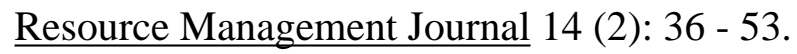

Guardian 27 March 2015. 'MP's slam construction firms over compensation for blacklisted workers': 2 .

Guney, Clark and Ryan, (2014) (http://www.guneyclarkryan.com/constructionindustry-blackllist-news 25 Nov 2013. Accessed 29/07/2014)

Heery, E., Conley, H., Delbridge, R. and Stewart, P. (2004) Beyond the enterprise: trade union representation of freelances in the UK Human Resource Management Journal 14 (2): 20 - 35.

Heery, E. and Simms, M. (2010) Employer responses to union organising: patterns and effects. Human Resource Management Journal 20 (1) 3 - 22

House of Commons Scottish Affairs Committee (2013) Blacklisting in employment: oral and written evidence. London, House of Commons, Stationery Office. Published on 16 April 2013. HC156-1.

House of Commons Scottish Affairs Committee (2014) Blacklisting in employment: addressing the crimes of the past; moving towards best practice. Sixth Report of session 2013-14; report together with formal minutes, oral and written evidence. House of Commons, London, Stationery Office. Published on 14 March 2014. HC543.

House of Commons Scottish Affairs Committee (2015) $\underline{\text { Seventh Report }}$ Blacklisting in Employment: Final Report. House of Commons, London, Stationery Office Information Commissioner's Office (2015/16) Information rights report Quarter 3 2015/16 Institute of Employment Rights (2013) The Blacklisting Scandal: a history of blacklisting, recent updates and how the law should be changed. Liverpool, IER. 
Kelly, J. (1998). Rethinking Industrial Relations: Mobilization, Collectivism and

Long Waves, London, Routledge.

Logan, J. (2006) The union avoidance industry in the United States. British Journal of Industrial Relations 44 (4): 651- 675

McIvor, A. (1988) 'A Crusade for Capitalism': The Economic League, 1919-1939, Journal of Contemporary History 23, 631-55

Mead, John M. and Gruneberg, Stephen (2013) $\underline{\text { Programme procurement in }}$ construction: learning from London 2012. Wiley Blackwell, Oxford.

Notes (Typescript) from Ian Kerr, dated 23/12. Inquiry into Blacklisting in

Employment. A selection of Ian Davidson MP's copies of papers provided to him by

Mrs M. Kerr. 2 of 11. http://www.parliament/uk/documents/commons-

committees/scottish-affairs/Blacklisting\%202.pdf. Accessed 17 November 2015.

Northrup, H. (1995) Doublebreasted operations and the decline of construction

unionism. Journal of Labor Research XVI (3) Summer.

Purcell, J. (1987) Mapping management styles in employee relations. Journal of Management Studies 24 (5) September: 533-548.

Purcell, J. and Ahlstrand, B. (1994) Human resource management in the multidivisional company. Oxford, OUP.

Roy, D. (1980) Fear stuff, sweet stuff and evil stuff: management's defences against unionization in the South. In Nichols, T. (Ed) Capital and labour: studies in the capitalist labour process. London, Athlone Press: 395-415.

Seely, A. (2015) Self-employment in the construction industry. House of Commons Briefing paper No 000196. 8 July 2015. London, House of Commons.

Smith, D. and Chamberlain, P. (2015) Blacklisted: the secret war between big business and union activists. Oxford, New International Publications. 
Syal, R. (2015) Building firms make court apology for blacklisting workers. Guardian 9 October 2015: 8 .

Union of Construction Allied Trades and Technicians (2014) Annual Return (AR21) as submitted to the Certification Office, London. http://www.gov.uk Accessed November 162015

Union of Construction Allied Trades and Technicians (2016) First UCATT blacklisted victims receive compensation. Press Release 9 February 2016 Wainwright, A. (2013) Alan Wainwright and the Construction Industry blacklist. http://alanwainwright.blogspot.co.uk/2013/07/frank-morris-blacklisting.html. Accessed 20/05/2014.

Wood, L. (1979) A union to build: the story of UCATT. London, Lawrence and Wright, C. and Brown, W. (2013) 'The effectiveness of socially sustainable sourcing mechanisms: assessing the prospects of a new form of joint regulation'. Industrial Relations Journal 44 (1): 20-37. 